\title{
Community-led social housing regeneration: from government-led programmes to community initiatives
}

Pablo Sendra

\section{Introduction}

The regeneration of social housing estates has been a major concern both in academia and in planning practices for the last few decades. Most of the attention has focused mainly on those social housing neighbourhoods built between World War II and the 1970s, both in Europe and in the USA. These neighbourhoods were built in different political and socioeconomic contexts depending on the country. Their location in the city also varied-for example, in Paris they were built mainly in the periphery, while in London many social housing estates were built in the inner city in places bombed during WWII or as part of the slum clearance process. The way governments have approached the regeneration or urban renewal of social housing has also varied from country to country and policies have been influenced by the context and the political inclination of the governments at each time (Couch et al. 2011). One of the key issues that central government and local authorities have attempted to address is the involvement of residents in the decision-making process for transforming their neighbourhoods. In many of the cases, in such neighbourhoods, there are groups at risk of exclusion. Participation and inclusion in the planning process is extremely relevant for these groups, to avoid displacement, to secure homes where social tenants can afford to pay the rent, and to make sure that regeneration brings opportunities to the residents. A critical concern is to ensure that regeneration does not have a negative impact on those deemed most at risk. 
Since each country has a very particular context, this paper will focus in the United Kingdom. More specifically, it will focus in London, which has a very different situation in terms of housing demand and affordability than the rest of the UK. As Edwards (2016) explains, the rise of housing prices, the shrunk of social housing, the re-conceptualisation of the term 'affordable' based on market rents, and the growth of inequalities in London have made housing unaffordable for low and medium income people. The period of study will be since the victory of the New Labour political party in the 1997 general elections until today. In this period, the central government and the local authorities have approached public participation in planning in different ways. Firstly, the involvement of citizens in urban regeneration schemes has been approached with different degrees of participation or steps on the participation 'ladder' (Arnstein 1969): from what Arnstein describes as 'degreees of tokenism' through consultation processes in Local Plans, to what Arstein labels as 'degrees of citizen power' through their participation in the boards of the New Deal for Communities (NDC), or through encouraging citizen-led initiatives through the Big Society approach and the Localism Act 2011 (LA 2011). Secondly, the approach to participation in social housing regeneration has also varied in the involvement of different actors - central government, local authorities, residents, private sector-in the decision-making process and in the sources of funding for different regeneration schemes.

Two episodes can be identified within the period of study. The first of these is the New Labour approach and its programme to regenerate deprived areas in the UK, which included many social housing estates. This programme provided large central government funding and also encouraged private investment in the regeneration process. The programme promoted community involvement by the inclusion of community representatives in the Partnership Boards, the decision-making organism (Beatty et al. 2008). The end of this programme coincided with the Global Financial Crisis in 2008, which was followed by the 
Coalition Government (Conservative Party and Liberal Democrats) after the 2010 general elections. One of the main flagships of the Conservative Party's campaign was the Big Society, a policy plan which proposed to give more power on decision making to local communities and also move from the state-led approach of the welfare state to a 'stateenabling' approach (Bailey and Pill 2015), where communities participate in the delivery of services. However, this approach coincided with strong austerity measures, which cut government investment in improving and providing social housing. One of the main implementations of the Big Society approach was the Localism Act 2011, followed by the publication of the National Planning Policy Framework (NPPF), which changed the planning system, the Local Plan guidance and the Neighbourhood Plan (NP) regulations in 2012. Concerning the NPPF, it abolished the Regional Strategies outside of London, giving more powers to local authorities. Local Plans and Neighbourhood Plans must comply with it (DCLG 2012). Neighbourhood Planning is one of the key novelties in the new planning system, since it allows - in places where there are no parish councils-groups of residents to apply to the local authority for designation of a Neighbourhood Forum (NF) and create a statutory plan led by the neighbours. Through Neighbourhood Planning, communities can decide the kind of future developments they want in their neighbourhood, as long as they do not contradict the Local Plan. Neighbourhood Planning does not come together with large regeneration funds. The government provides small amounts of funding for producing the NP. It does not provide direct funding for implementing neighbourhood projects or improvements associated with a NP, but it provides an incentive through a share of the Community Infrastructure Levy (CIL) coming from developments in the area for those communities that manage to get their NP approved by referendum (DCLG, 2014). 
In this current era of austerity, there are also other community-led initiatives, which are not carried out through Neighbourhood Planning or other planning tool introduced by the LA 2011, where residents look for alternative sources of funding such as crowdfunding or fundraising to develop neighbourhood projects that improve their neighbourhoods. These initiatives vary in scale and scope. In neighbourhoods where residents have a strong capacity to self-organise and seek for funding, this can be an effective way to develop community-led initiatives without the necessity of making a NP.

If we look at the two models - the government-led regeneration schemes and the Big Society-from the social housing regeneration perspective, there is a clear shift in how participation is approached, on the role of residents, local authority, central government and the private sector, and on where the funding comes from. The aim of this paper is not to compare and evaluate these two models, but to study how they have addressed the involvement of residents in council estate regeneration in order to address they following question: How can local authorities — and the central government—provide tools, sources of funding and means to encourage and ease either the genuine involvement of residents or coproduction processes in council estates regeneration?

\section{Methodology}

In addressing this question, this paper will study how the involvement of residents has taken place in three situations: firstly, it will look at the participation of residents in the Partnership Boards of the NDC, secondly, it will examine Neighbourhood Planning as a tool to propose a community-led estate regeneration plan, and thirdly, it will explore other initiatives that have obtained other sources of funding to build a neighbourhood project to improve a council estate. 
In doing so, each of the three sections will examine both policy context and cases of community involvement. The analysis of the policy context will explore how public participation has been approached in planning guidance, regulations and other documents. The analysis of cases of community involvement will examine strengths and weaknesses in the process. For the NDC, it will look at the two NDC areas with different outputs: the Aylesbury Estate in South London, which found strong opposition from the residents, and EC1, a series of social housing neighbourhoods in Central London where significant improvement in the public realm and community spaces were carried out. For examining Neighbourhood Planning, it will use Greater Carpenters Neighbourhood Forum (GCNF) as case study, a council estate in East London that is trying to avoid demolition by putting together a NP that proposes refurbishment and infill new homes. Sagoe (2016) has explored the 'political potential' of Neighbourhood Planning to stop government-led urban renewal in the case of GCNF. This section of the paper, by looking at information collected from the Local Plan and other planning documents, from the recently published draft of the NP, from the websites of the local authority and of GCNF - and also building on Sagoe's (2016) reflection-will examine the public participation mechanisms in the current planning system to propose a community-led council estate regeneration plan. Finally, the paper will also analyse cases were communities have raised funding to propose and implement a project to improve the neighbourhood led by the residents. It will look at the Ebony Horse Riding Club next to Loughborough Estate in South London and at the community-led restoration of the park in Alexandra Road Estate in North London.

\section{New Deal for Communities}

During the post-war period and until the 1970s, a great number of social housing neighbourhoods were built by local authorities as part of the welfare programme, which 
aimed to provide housing and health care for everyone. When Margaret Thatcher came to power in the 1979, there was a change in approach to urban regeneration (Couch et al. 2011) and provision of local authority housing almost stopped (Edwards 2016). As Jacobs and Lees (2013) discuss, Thatcher's approach to the regeneration of council estates focused in privatisation - through the Right to Buy, implemented in 1980 - and was also influenced by Alice Coleman's book Utopia on Trial: Vision and Reality in Planned Housing (Coleman 1985), who had exported Newman's (1972) Defensible Space ideas for designing out crime to the UK. In the 1990s, under the following Conservative government, the regeneration approach of Area-Based Initiatives (ABI) was introduced through the Single Regeneration Budget (SRB) in 1994 and lasted until 2004. The SRB aimed to bring more economic opportunities and improve deprived areas. It encouraged local partnerships between local authorities, the voluntary and the private sector to carry out regeneration projects. It introduced the competitive bidding system, in which any area in England could apply. It had a flexible approach, in which the partners decide the boundaries, the duration and the scope of the project (Tyler et al. 2007). The SRB approach had a strong influence in the NDC, later launched by the New Labour government in 1998, which also lasted for 10 years (Batty et al. 2010).

The victory of New Labour's Tony Blair in the 1997 general elections also had an impact on the approach to council estate regeneration. As Campkin (2013) describes, Blair's campaign had a strong focus on council estate regeneration. Blair gave his first speech as Prime Minister in the Aylesbury Estate, one of the neighbourhoods that will be later designated as one of the 39 areas in the NDC. The government saw the decline of council estates as a failure of previous Conservative governments, which, according to Blair's speech at the Aylesbury Estate, had forgotten the poorest people in the country for 18 years, and proposed the regeneration of these places. 
The NDC programme was launched almost at the same time as the 'Urban Renaissance' proposed by the Urban Task Force (UTF) (UTF 1999). The government appointed a group of experts led by the architect Richard Rogers to set a new urban agenda that would influence development in the beginning of the $21^{\text {st }}$ century. The UTF's report was strongly influenced by the success of Barcelona as a compact city—with high density and mix of uses - in the 1990s, which had had a strong leadership in the City Hall with Pasqual Maragall as Mayor and had invested in urban regeneration programmes. This was clearly reflected when the Royal Institute of British Architects awarded the Royal Gold Medal to the City of Barcelona, and also by the fact that Pasqual Maragall writes the foreword of the final report of the UTF. Its fifth chapter, 'Delivering urban regeneration', makes a series of recommendations for council estate regeneration process, which particularly looks at how the partners, the local authorities, private organisations, partners and committees should coordinate in regeneration processes. It advocates for public spending and also for attracting private investment. The set of recommendations does not mention mechanisms for the community involvement in decision-making (UTF 1999). Chapter 4 on 'Managing the urban environment', addresses the importance of community involvement by proposing the neighbourhood management models 'which give local people a stake in decision-making process' (UTF 1999, p.123).

The NDC ran between 1999/2000 and 2007/2008. It was also an ABI but, in this case, it targeted 39 deprived areas, investing an average of $£ 50$ million per area, with the aim of bridging the gap between these areas and the rest of the country. One of the key objectives of the NDC was to "place the community 'at the heart of' the initiative" (Batty et al. 2010, p.5), highlighting the importance that this programme gave to the involvement of residents in regeneration processes. The final assessment of the NDC emphasises the effort of the partnerships to "involve local people in the planning, design, delivery and review of their 
local programmes" (Batty et al. 2010, p.32) and the representation of residents in the NDC boards. However, it also notes that only a small number of residents were directly involved in the decision-making process. Further, it explains that "social capital indicators such as people thinking they can influence local decisions" (Batty et al. 2010, p.28) did not improve. The report determines that this raises questions about the governance structures for participation, the influence that residents priorities should have on the allocation of resources, and the confrontation between views of residents and professionals (Batty et al. 2010). In general, the report affirms that community engagement is important and it requires "consistency, dedication and commitment" (Batty et al. 2010, p.33).

NDC Partnerships worked differently in each of the 39 areas and it is necessary and the involvement of the residents in the regeneration had different outputs. As the final report suggests, the involvement of residents has a very positive effect on how they feel about the regeneration scheme (Batty et al. 2010). The response of residents to the scheme also depends on whether the regeneration considers refurbishment or demolition. In the case of Aylesbury Estate NDC, the original NDC plan was the stock transfer from the council to a 'community based housing association' and the demolition and redevelopment of the estatebased on how the council describes it in its report 'The Aylesbury Estate: Revised Strategy' (see LBS 2005). This would secure additional $£ 400 \mathrm{~m}$ from the stock transfer in addition to the $£ 52 \mathrm{~m}$ funding from the government. The residents rejected with a large majority this stock transfer and redevelopment scheme in a ballot, were $73 \%$ of the residents voted against it and $73 \%$ turnout. In the council report to revise the strategy for the Aylesbury Estate (LBS 2005), a number of factors that caused residents to vote against the redevelopment were identified. These included perceptions that the campaign for redevelopment was weak, that the residents organised a campaign against the scheme, and that residents were concerned that the stock transfer would results in higher rents and service charges. Despite the result of 
the resident ballot, the council's revised strategy still consisted of a demolition and redevelopment approach (LBS 2005). The report showed figures indicating the costs of refurbishment, presenting this option as non-viable and explaining that the only viable option is demolition and redevelopment.

This is just one of the 'chapters' of a long story of plans for redevelopment for the Aylesbury Estate (see 35\% Campaign n.d.; Lees 2014; Campkin 2013). Much of the opposition to demolition comes from the fear of displacement. Lees (2016) has studied the negative effect that council estate demolition has on its residents, as she shows in the maps tracking the displacement of the residents. This displacement also affects the leaseholders, who go through a Compulsory Purchase Order (CPO) and, with the compensation they receive for their home, they can no longer afford to buy a property in the area. In the case of Aylesbury Estate, this was challenged by a Public Inquiry by leaseholders and the Secretary of Estate of Communities and Local Government finally refused the council's application for CPO from the leaseholders in September 2016 because of the effect it would have on elderly, children and ethnic minority groups (Rendell 2017; 35\% Campaign, n.d.).

Figure 1: Aylesbury Estate block from Burgess Park. September 2016. Image by the author.

There are other NDC programmes that have not contemplated redevelopment and has focused in other improvements of the built environment and on social programmes. The NDC EC1, in the fringe of Central London, is an example of an NDC programme where regeneration does not imply redevelopment but the refurbishment of homes, public spaces and community facilities. In addition to social programmes, the NDC included the improvement of public and communal spaces of the area, community facilities, and making the existing houses safer and of better quality (LBI 2010). In their public space strategy, 
"steering groups of residents and professionals were set up for each of the projects, and were involved throughout the whole process of consultation, design and delivery" (LBI 2010, p.6). However, the final evaluation report by the council recognises that resident involvement was limited to the participation of some of them on the board, and that the projects "could have widened participation by connecting more closely with a layer of active community members beyond those on the board" (LBI 2010, p.8). The involvement of residents beyond their representation on boards is a major challenge on participation. As the final report of the NDC highlights (Batty et al. 2010), one of the difficulties of the NDC is how to engage actively a larger proportion of the population on the regeneration scheme.

\section{Neighbourhood Planning and council estate regeneration}

This section will analyse the policy context after the Coalition Government came to power in the 2010 elections and examine the strengths and limitations of Neighobourhood Planning as a tool for community-led social housing regeneration.

The end of the NDC programme coincided with the 2008 Global Financial Crisis and with the Coalition Government after the 2010 general elections. One of the flagships of the Conservative Party's campaign for the elections was the Big Society, which changed the state-led approach from 1993 to 2010 to the 'state-enabling' approach after 2010 (Bailey and Pill 2015). The Coalition Government also implemented the localism agenda, which aimed to give more power to local authorities. This localism agenda came together with severe austerity measures, which decreased considerably government funding in council estate regeneration and cancelled ABI programmes such as the NDC (Lupton and Fitzgerald 2015).

Since ABI programmes finished in 2010, local authorities were in charge of carrying out - and seeking funding for-council estate regeneration schemes. This lack of funding 
from central government has been used on multiple occasions by local authorities to explain why refurbishment options are not viable, resulting in the need to find other solutions for the provision of social and affordable housing, such as selling the land to private developers or creating special purpose vehicle companies owned by the council to carry out regeneration and redevelopment schemes.

The Localism Act 2011 is the implementation of the Big Society and localism approaches. It offers local authorities more control over development through the abolition of Regional Strategies (except the London Plan) as well as wider community involvement through Neighbourhood Planning, a new planning framework through which communities can create a statutory plan that guide future developments in their neighbourhood (Locality 2016).

An NP coming into force needs to go through a series of stages. When there is no Parish Council, which is most of the cases in Greater London, community groups have to decide the boundaries of the Neighbourhood Area and apply to the local authority for the designation of the Neighbourhood Area and Neighbourhood Forum (Locality 2016). Once it is designated, the Forum develops the NP and submit it to the local authority. After being checked by the local authority and going through independent examination, the NP goes to referendum. If it is approved by a majority over $50 \%$, it is brought into force and becomes a statutory planning framework (Locality 2016).

Neighbourhood Planning has the potential to bring wider community participation. However, there are some difficulties when Neighbourhood Planning is used as a tool for putting together a community-led plan for council estate regeneration based on refurbishment and infill, particularly when this is different from the council's objectives (see Sagoe 2016). Among the obstacles that residents can find in the process, there are three important difficulties. Firstly, it needs high levels of self-organisation, commitment by residents and 
can be found as a 'burdensome' process (Parker et al. 2014; referenced in Civil Exchange 2015). This difficulty can particularly affect council estate residents, since they can have fewer resources than others to carry out this process. Secondly, the NP cannot contradict or oppose the Local Plan. In the case of council estate regeneration, if the local authority is planning to demolish and redevelop a council estate, it is very difficult for residents to oppose this and propose an alternative plan based on refurbishment and infill homes. Local authorities make decisions on the designation of Neighbourhood Forums and Neighbourhood Areas, in cases where there is no parish council, as it happens in most places in London, and also check the NP once this is submitted. Thirdly, if the NP is finally brought into force, the funding for implementing it depends on the new developments that take place in the area. Currently, the central government provides funding for encouraging the creation of NPs and for developing it. However, for delivering the public infrastructure or improvements in the neighbourhood, there is not a large pot of funding from the central government as was the case in ABIs like SRB or the NDC. Instead, communities that manage to bring a NP into force receive $25 \%$ or the CIL arising from developments in their area (DCLG 2014). This approach means that the funding for implement the NP is subject to the amount of development that takes place in the area.

One council estate that is currently using Neighbourhood Planning as a tool to resist demolition, proposing an alternative plan based on refurbishment and infill, is the Carpenters Estate. This is located in the London Borough of Newham (LBN), in East London, at the border of the Olympic Park. The council estate has been subject to demolition and redevelopment since 2011, when LBN and University College London (UCL) announced a memorandum of understanding to build the UCL East Campus in the area of the council estate (Frediani et al. 2013). UCL decided to withdraw the intention to build the east campus in the Carpenters site in 2013. A group of residents who campaigned against the demolition 
of the estate started working together with businesses, Just Space (a network of community organisations), the London Tenants Federation, and UCL academics and students to put together a community plan (JSEP 2015). After this, the group decided to continue working together to put together a NP.

The Carpenters Estate is in a particular situation, since the land is owned by Newham council but, since 2012, its planning authority is the London Legacy Development Corporation (LLDC). This means that developments must be done according to the LLDC Local Plan. As a result of this situation, the residents successfully applied for designation of the Neighbourhood Forum and Area to the LLDC and formed the Greater Carpenters Neighbourhood Forum (GCNF), which includes a larger area than the council estate. As Sagoe (2016) reflects, in order to make Neighbourhood Planning a successful strategy to oppose demolition a propose alternatives, it needs to go together with other strategies and engagement with planning. In the case of GCNF, their participation in the consultation process for the LLDC Local Plan has been key in the process, since they have managed to introduce amendments in the LLDC Local Plan for "protecting existing housing stock" (LLDC 2014, p.44) as part of the housing strategy and other amendments to the Site Allocation for Greater Carpenters, which includes "support of the preparation of a Neighbourhood Plan” (LLDC 2015, p.2).

At the time of writing, they have produced a draft of a NP at the beginning of 2017 (GCNF 2017). In parallel, Newham council is seeking for partners to redevelop the estate (LBN 2017). These two initiatives, the one led by GCNF and the one led by Newham council, seem to confront, since one is proposing redevelopment and the other one refurbishment and sensitive infill. The future seems uncertain, which makes it an interesting case to follow in order to explore whether this can finally lead to a truly community-led plan for social housing regeneration. 


\section{Civic entrepreneurship in council estate regeneration}

This section will explore cases where community groups, in the current context of austerity, have raised funding to develop their initiatives in council estates.

The post-2008 Global Financial Crisis and the austerity measures coincided with the emergence of what has been named as the 'civic economy' (00:/ 2011). The civic economy describes when individuals, communities and other groups come together to co-produce public spaces, community facilities or improve the local economy. It is not accurate to say that this has come as a response to the Global Financial Crisis, to the austerity measures nor to the Big Society approach; this approach, of civic entrepreneurship, came from before the economic crisis (00:/ 2011). These kind of initiatives can have different scales. In some cases, they are small interventions that then have strong impact (see Alanis Arroyo el al. 2015) and have the potential to become larger initiatives. One of their characteristics is that their outputs are tangible - whether they are physical and/or social—and this can motivate to further change.

These kind of initiatives work in a different way from the planning framework proposed by the Localism Act 2011. As discussed, Neighbourhood Planning can be a difficult and long process (Parker et al. 2014; referenced in Civil Exchange 2015). And once the NP is brought forward - in many cases with substantial modifications by examiners (Parker et al. 2017) - the funding for implementing it will depend on developments taking place in the area. In contrast, other civic initiatives that has not used this planning framework work on mid-term tangible outputs, on specific projects. This does not mean that both approaches are incompatible. These civic initiatives can work together or form part of a long-term vision and could be combined in some cases with a NP. 
Civic initiatives to implement improvements in the public spaces, services or community facilities are funded through different kinds of sources. In some cases, the funding can be raised through a time-limited crowdfunding campaign, such as the ones run by the platform Spacehive, where projects need to raise a minimum target in a limited period of time to be successful, or other fundraising online platforms, where there is not a limit of time, and funding is continuously collected to start or maintain a project. In other cases, community initiatives can apply to bigger funding schemes to deliver specific projects in their neighbourhoods.

Public authorities have seen this as an opportunity to promote civic engagement and to provide small funding to encourage these initiatives. An example of this is the Mayor of London Crowdfunding Initiative, now rebranded as Crowdfund London, done in partnership with the platform Spacehive (see Spacehive n.d.). This initiative is to fund community projects and civic initiatives with an output, and the Mayor of London pledges with up to $£ 50 \mathrm{k}$ the proposals (based on their criteria, which includes quality of the proposal, deliverability, value for money, and strength of support), and this adds to the money raised by other donations through the platform.

The question remains as to whether these kind of civic projects can be done within the context of council estate regeneration. The Big Society has been criticised for leaving behind the most disadvantaged (Civil Exchange 2015), which is a further outcome of cuts in public services. This chapter does not present civic entrepreneurship and fundraising run by the community as the way to fund council estate regeneration, but presents examples with positive outcomes that can help to understand how community-led projects can work to improve neighbourhoods.

The Ebony Horse Club, although it cannot be described as council estate regeneration, is an example of a community project that starts at a council estate youth club, becomes a 
charity and manages to build horse riding club in the park next to a council estate in Brixton, South London. The initiative started by providing horse riding activities for young people in the youth club of Moorland Estate in Brixton (see Jardine 2010; Briton Pound 2015; Ebony Horse Club n.d.), taking young people to ride horses in a stable in Kennington. This initiative was later turn into a charity named Ebony Horse Club. The charity got planning permission to build its own horse riding club in Wyck Gardens, which next to Loughborough Estate, also in Brixton. While they were raising funds for building their facilities, they had their office in the community centre of Loughborough Estate. They raised $£ 1.6 \mathrm{~m}$ through a strong fundraising campaign, awards and different funding sources (see Jardine 2010; Brixton Pound 2015). In 2011, they opened their new premises near Loughborough Estate. Since then, young children for the area have the opportunity to practice horse riding and this is having a very positive impact in young people, since provide support them, work with them on their aspirations and on their social relationships (Brixton Pound 2015). It has also had a positive impact on Wyck Gardens, where horse riding take place, a more activities happen in the public realm. This case is a project with very tangible outputs, both physical and social: Wyck Gardens has a new amenity and activities, and, in addition to this, it is providing support and leisure to young people in the area. Although it is not directly a regeneration strategy for Loughborough Estate, it has a positive impact on its built environment and on its young people.

Figure 2: Ebony Horse Club and a block of Loughborough Estate. August 2012. Image by the author.

Alexandra Road Park is a case of improvements on a council estate initiated by residents. Alexandra Road Estate is a council estate located in the London Borough of 
Camden. It has a very particular situation, since the estate is Grade II* Listed. Its listing, in 1994, was the result of an initiative from a resident of the estate and it was the first modernist housing estate to be listed (Alexandra and Ainsworth Estate TRA n.d.). More recently, in 2010 a group of residents decided to apply to Heritage Lottery Fund, to the 'Parks for People' programme for the restoration of the park (Friends of Alexandra Road Park n.d.). The application process was in two stages: on the first stage they applied for funding for developing the plan and design, and in the second phase they applied for funding for carrying out the restoration of the park. After working in collaboration with Camden council and with the project team they managed to get the funding to restore the park in 2013 and the restored park was opened in 2015. The restoration consisted on 'new purpose made playgrounds', 'restoring all the paths', and 'revitalising the planting with new plants, shrubs and trees' (Friends of Alexandra Road Park n.d.). These resident-led initiatives has allowed to keep the estate in its original form and has also allowed to apply for funding for refurbishment. The fact that the building is listed has protected it from demolition and any kind of alteration. As their website explains, the initiative to list it came from the residents' dissatisfaction with the maintenance of the estate. Then, its heritage value has allowed the residents to obtain Heritage Lottery Fund to restore one of its public spaces. Although this is again a very specific situation - a building with an iconic architecture that manages to be listed-it is nevertheless a good example on how community initiatives can bring improvements to a council estate.

Figure 3: Alexandra Road Park. September 2015. Image by the author.

\section{Conclusions}


This chapter has looked at how the central government and local authorities have provided tools and sources of funding to encourage the involvement of residents in council estate regeneration, looking at the NDC programme during the New Labour government, Neighbourhood Planning, and other community initiatives that have fundraised to build their neighbourhood project.

Regarding the participation and community involvement mechanisms, the NDC introduced the representation of residents in the partnership boards. This guaranteed a certain degree of community involvement. However, it limited the participation to those in the board and did not succeeded in involving actively a large proportion the communities. It cases like the Aylesbury Estate, where residents felt the redevelopment could involve displacement or higher rents, it created conflictive visions between the residents and the council. Neighbourhood Planning, in principle, is community-led and residents can guide the future of their neighbourhood. However, there are substantial limitations: firstly, it cannot contradict the Local Plan, which means it is difficult to stop the council from redeveloping a council estate. However, residents can participate in the consultation process of the Local Plan and have a say on how the Local Plan addresses their neighbourhood. Secondly, Neighbourhood Planning is a long and difficult process, which requires high levels of commitment from the neighbours. Regarding other community initiatives that raise funding to build projects which improve their council estate, such as the cases of Ebony Horse Club and Alexandra Road Park, they do not have the constraints of Neighbourhood Planning. However, communities need high levels of self-organisation, to raise funding, apply for planning permission, and collaborate with the landowner, (normally the local authority) to deliver the project.

The funding model also varies in the three situations studied. Under the NDC, there was large funding available from the central government, which was a good incentive for regeneration and for supporting partnerships with local authorities, private and voluntary 
sectors. However, this funding only targeted 39 areas, while there were many other areas and council estates which also needed funding for regeneration (UTF 1999). For Neighbourhood Planning, there is a small amount of funding to assist with putting together the NP. However, the funding for implementing the plan depends on the amount of development in the area. In the case of community initiatives for projects in the estate, the sources of funding are fundraising campaigns, as in the case of Ebony Horse Club, or specific schemes for funding, like the case of Alexandra Road Park.

From the cases studied, it can be concluded that community participation needs easier processes, which do not require such a strong effort from community groups, and which do not require a long process to see the first tangible outputs. For council estates, particular support is needed to encourage the residents to be actively involved in the process and avoid regeneration processes that cause displacement or negative impacts on its residents. It is also necessary to have funding sources that specifically target these communities. This support and funding sources can, firstly, serve as an incentive to be more actively involved in the regeneration of their neighbourhood, and secondly, do not rely on private investment and development for the improvement of council estates.

\section{Acknowledgements}

This piece of research has been carried out with the support of a British Academy/Leverhulme Small Grant.

\section{References}

00:/ (2011). Compendium for the Civic Economy. London: 00:/ in association with Nesta and CABE. $\quad$ http://www.nesta.org.uk/assets/features/compendium_for_the civic_economy. Accessed 7 April 2012. 
35\% Campaign (n.d.). Aylesbury Estate. http://35percent.org/aylesbury-estate/. Accessed 30 May 2017.

Alanís Arroyo, A., Carrascal Pérez, M. F., González Martínez, P., Sendra Fernández, P. 2015. Un mapa de relatos urbanos. Laboratório Q de lugares de creatividad urbana. Revista dearq 16, 44-59.

Alexandra and Ainsworth Estate Tenants and Residents Association (n.d.). Alexandra and $\begin{array}{llll}\text { Ainsworth } & \text { Estate } & \text { Tenants and }\end{array}$ https://alexandraroadestate.wordpress.com. Accessed 31 May 2017.

Arnstein, S.R. (1969). A Ladder Of Citizen Participation. Journal of the American Institute of Planners, 35(4), 216-224. doi: 10.1080/01944366908977225

Bailey, N. \& Pill, M. (2015). Can the state empower communities through localism? An evaluation of recent approaches to neighbourhood governance in England. Environment and Planning C: Government and Policy 33, 289-304. doi:10.1068/c12331r

Batty, E., Beatty, C., Foden, M., Lawless, P., Pearson, S., Wilson, I. (2010). The New Deal for Communities Experience: A final assessment. The New Deal for Communities Evaluation: Final report - Volume 7. Department for Communities and Local Government. 
Beatty, C., Foden, M., Lawless, P., Wilson, I. (2008). New Deal for Communities: A Synthesis of New Programme Wide Evidence: 2006-07. NDC National Evaluation Phase 2. Research Report 39. Department for Communities and Local Government.

Brixton Pound (2015). \#Brixton Fund - Local Group of the Month: Ebony Horse Club. http://brixtonpound.org/blog/2015/10/07/brixton-fund-local-group-of-the-month-ebony-

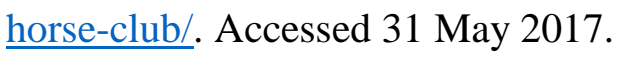

Campkin, B. 2013. Remaking London: Decline and regeneration in urban culture. London: I.B. Tauris.

Civil Exchange (2015). Whose Society? The Final Big Society Audit. http://www.civilexchange.org.uk/wp-content/uploads/2015/01/Whose-Society_The-FinalBig-Society-Audit_final.pdf. Accessed 3 March 2017.

Coleman, A. (1985). Utopia on trial: vision and reality in planned housing. Revised edition 1990. London: Hilary Shipman.

Couch, C., Sykes, O., Börstinghaus, W. (2011). Thirty years of urban regeneration in Britain, Germany and France: The importance of context and path dependency. Progress in Planning 75: 1-52. doi:10.1016/j.progress.2010.12.001

Department for Communities and Local Government (2012). National Planning Policy Framework. 
https://www.gov.uk/government/uploads/system/uploads/attachment_data/file/6077/2116950. pdf. Accessed 31 May 2017.

Department for Communities and Local Government (2014). Community Infrastructure Levy. https://www.gov.uk/guidance/community-infrastructure-levy. Accessed 31 May 2017.

Ebony Horse Club (n.d.). About Ebony Horse Club. http://www.ebonyhorseclub.org.uk/about-ebony-horse-club. Accessed 31 May 2017.

Edwards, M. (2016). The housing crisis and London. City, 20 (20), 222-237. doi: 10.1080/13604813.2016.1145947.

Frediani, A., Butcher, S., Watt, P. (2013). Regeneration and Well-Being in East London: Stories from Carpenters Estate. Development Planning Unit, UCL. https://www.bartlett.ucl.ac.uk/dpu/programmes/postgraduate/msc-social-developmentpractice/in-practice/london-based-fieldwork/carpentersreport. Accessed 13 June 2016.

Friends of Alexandra Road Park (n.d.). Restoring the park. https://friendsofalexandraroadpark.com/about/restoring-the-park/. Accessed 31 May 2017.

Jacobs, J.M. \& Lees, L. (2013). Defensible Space on the Move: Revisiting the Urban Geography of Alice Coleman. International Journal of Urban and Regional Research, 37 (5), 1559-1583. doi: 10.1111/1468-2427.12047. 
Jardine, C. 2010. Ebony Horse Club: the ride of their lives. The Telegraph. http://www.telegraph.co.uk/active/7748790/Ebony-Horse-Club-the-ride-of-their-lives.html. Accessed 31 May 2017.

Just Space Economy and Planning. (2015). London for all! A handbook for community and small business groups fighting to retain workspace for London's diverse economies. Just Space and New Economics Foundation.

Lees, L. (2014). 'The Urban Injustices of New Labour's "New Urban Renewal": The Case of the Aylesbury Estate in London'. Antipode 46 (4), 921-947. doi: 10.1111/anti.12020.

Lees, L. (2016). Cameron's 'sink estate' strategy comes at a human cost. The Conversation. http://theconversation.com/camerons-sink-estate-strategy-comes-at-a-human-cost-53358. Accessed 31 May 2017.

Locality, 2016. Neighbourhood Plans Roadmap Guide. http://locality.org.uk/wpcontent/uploads/Neighbourhood-planning-roadmap-2016.pdf. Accessed 3 January 2017.

London Borough of Islington, 2010. EC1 NDC: A final evaluation. https://www.islington.gov.uk// /media/sharepoint-lists/publicrecords/democracy/qualityandperformance/reporting/20112012/20120303ec1newdealforcom munities. Accessed 31 May 2017. 
London Borough of Newham (2017). Carpenters Estate newsletter update - March 2017. https://www.newham.gov.uk/Documents/Business/CarpentersEstateNewsletterUpdateMarch 2017.pdf. Accessed 19 April 2017.

London Borough of Southwark (2005). The Aylesbury Estate: Revised Strategy. http://moderngov.southwark.gov.uk/Data/Executive/20050927/Agenda/Item\%2007\%20\%20The\%20AylesburyEstate\%20Revised\%20Strategy\%20-\%20Report.pdf. Accessed 30 May 2017.

London Legacy Development Corporation. (2014). Local Plan 2015 to 2031. http://www.queenelizabetholympicpark.co.uk/ /media/lldc/local\%20plan/local\%20plan\%20a ug14/local\%20plan.pdf. Accessed 19 April 2017.

London Legacy Development Corporation. (2015). Site Allocation SA3.4 - Greater Carpenters District. $\quad$ http://www.queenelizabetholympicpark.co.uk/-/media/lldc/local-plan/31-march/siteallocation-sa34-response-to-inspector-31st-march-2015.ashx?la=en. Accessed 24 May 2017.

Lupton, R. \& Fitzgerald, A. (2015). The Coalition's Record on Area Regeneration and Neighbourhood Renewal 2010-2015. Social Policy in a Cold Climate, Summary Working paper 19. London School of Economics and Political Sciences. http://sticerd.1se.ac.uk/dps/case/spcc/wp19.pdf. Accessed 6 March 2016.

Newman, O. 1972 Defensible space: crime prevention through urban design. New York: Macmillan. 
Parker, G., Lynn, T., Wargent, M. (2014) User experience of neighbourhood planning in England. London: Locality. http://mycommunity.org.uk/wp-content/uploads/2016/08/Userexperience-executive-study.pdf. Accessed 31 May 2017.

Parker, G., Lynn, T., Wargent, M. (2017): Contestation and conservatism in neighbourhood planning in England: reconciling agonism and collaboration?, Planning Theory \& Practice. doi: 10.1080/14649357.2017.1316514

Rendell, J. (2017). 'Arry's Bar: condensing and displacing on the Aylesbury Estate. The Journal of Architecture. doi: 10.1080/13602365.2017.1310125.

Sagoe, C. (2016). One Tool Amongst Many: Considering the Political Potential of Neighbourhood Planning for the Greater Carpenters Neighbourhood, London. Architecture, Media, Politics and Society, 9(3), 1-20. doi: 10.14324/111.444.amps.2016v9i3.001

Spacehive (n.d.). Crowdfund London. https://www.spacehive.com/movement/mayoroflondon. Accessed 31 May 2017.

Tyler, P., Rhodes, J., Brennan, A., Warnock, C., Stevens, S., Otero-García, M. (2007). The Single Regeneration Budget: final evaluation. Urban Research Summary. Number 25. Department of Communities and Local Government.

Urban Task Force (1999). Towards an Urban Renaissance. London: Department of the Environment, Transport and the Regions. 